\title{
REVIEW
}

\section{Colchicine Against SARS-CoV-2 Infection: What is the Evidence?}

\author{
Alexandros A. Drosos (1) - Eleftherios Pelechas (1) - Vassiliki Drossou (1) · \\ Paraskevi V. Voulgari
}

Received: November 21, 2021 / Accepted: January 20, 2022 / Published online: February 2, 2022

(C) The Author(s) 2022

\begin{abstract}
Coronavirus disease 2019 (COVID-19) caused by the severe acute respiratory syndrome coronavirus 2 (SARS-CoV-2) is a matter of concern worldwide and a huge challenge for rheumatologists. Indeed, several antirheumatic drugs are currently used at different stages of COVID19 , such as several cytokine inhibitors and colchicine. Colchicine is one of the oldest medicines with potent anti-inflammatory properties. In rheumatic diseases it is widely used for the treatment of gout, calcium pyrophosphate deposition disease, and familial
\end{abstract}

\footnotetext{
A. A. Drosos (囚) - E. Pelechas - V. Drossou .

P. V. Voulgari

Rheumatology Clinic, Department of Internal

Medicine, Medical School, University of Ioannina,

45110 Ioannina, Greece

e-mail: adrosos@uoi.gr

URL: https://www.rheumatology.gr

E. Pelechas

e-mail: pelechas@doctors.org.uk

V. Drossou

e-mail: drossou.v@gmail.com

P. V. Voulgari

e-mail: pvoulgar@uoi.gr
}

Mediterranean fever. It is also used off-label in cardiology to treat atrial fibrillation, pericarditis, and myocardial infarction. Over the last few years, advances in the understanding of colchicine's mechanism of action and its pharmacology and safety have made colchicine a promising candidate agent for the fight against COVID-19. In this review, we discuss COVID-19 pathophysiology highlighting colchicine's mode of action, its pleiotropic effects on neutrophils, inflammasome inhibition, and its viral activity. Finally, we discuss the main clinical studies dealing with the use of colchicine in COVID-19. Given the large body of evidence that demonstrates its effectiveness, safety, and its simple way of administration, colchicine seems to be a promising drug to reduce the risk of severe COVID-19 disease.

Keywords: COVID-19; Colchicine; SARS-CoV-2 infection; Inflammasome; Neutrophils; Gout; FMF; Cytokine release syndrome 


\section{Key Summary Points}

Systemic and uncontrolled inflammation of the innate and adaptive immune system is the hallmark of COVID-19 disease.

In the absence of effective treatment, offlabel drugs are used, among them colchicine.

Colchicine interferes with several inflammatory pathways including chemotaxis, adhesion and activation of neutrophils, inflammasome activation, and cytokine release.

Given the fact that colchicine is effective, well tolerated, inexpensive, and has a simple dosage scheme, it seems to be a promising drug to reduce the risk of severe COVID-19 disease.

\section{INTRODUCTION}

Systemic inflammation is the hallmark of coronavirus disease 2019 (COVID-19) caused by the severe acute respiratory syndrome coronavirus 2 (SARS-CoV-2). The result is an exaggerated inflammatory response of the innate and adaptive immune system known as cytokine release syndrome (CRS). When CRS occurs, several immunological alterations are taking place such as the production and secretion of a plethora of pro-inflammatory cytokines like interleukin (IL)-1 $\beta$, IL-6, IL-18, and tumor necrosis factor alpha (TNF $\alpha)$ [1]. COVID-19 is a matter of concern and a huge challenge for the rheumatologists dealing with patients suffering from autoimmune rheumatic diseases (ARD), because several antirheumatic drugs are used at different stages of COVID-19 [2-4]; these drugs include colchicine and cytokine inhibitors against IL-1 $\beta$, IL-6, and TNF $\alpha$ [3-5]. However, none of the aforementioned treatment regimens have been proven to be completely efficacious. Colchicine is an old drug which has been used for many years to treat gout, calcium pyrophosphate deposition disease (CPPD), and familial Mediterranean fever (MMF). Colchicine is used off-label for some heart diseases, like pericarditis, atrial fibrillation, and myocardial infarction [6, 7]. However, over the last few years, advances in the understanding of colchicine's mechanism of action, pharmacology, and safety have changed treatment perspectives for this old drug [8]. Indeed, during the last year it has been used as a potential therapeutic agent against SARS-CoV-2. As physicians gain more experience from its use, there are some contradictory results with encouraging data on one side that favor its use [9] and data that supports its ineffectiveness on the other side [10]. In this review, we discuss COVID-19 pathophysiology highlighting colchicine's mode of action, its pleiotropic effects on neutrophils, inflammasome inhibition, and its viral activity, and we try to give answers to the aforementioned argument, after searching the relevant literature. This study was performed in accordance with the Helsinki Declaration of 1964 and its later amendments.

\section{SEARCH STRATEGY}

In this narrative review, we searched Medline and Scopus for clinical studies evaluating colchicine for COVID-19. More specifically, we searched for double-blind randomized, openlabel randomized, placebo-controlled, cohort, case control, cross-sectional, observational, and retrospective studies.

\section{SARS-COV-2 INFECTION}

SARS-CoV-2 is a single-stranded RNA (ssRNA) virus that belongs to the coronavirus family. Coronavirus has an enveloped spherical morphology. The virus affects the host's cells through its receptor-binding domain, which is located in the subunit S1 of the S protein. This receptor can attach to the host's cell receptor angiotensin-converting enzyme 2 (ACE2), located on the cell membrane and invade mostly 
the epithelial and alveolar cells of the respiratory system. ACE2 is also frequently present in endothelial cells of many vessels, heart, kidneys, and other tissues [11]. Clinical manifestations of COVID-19 range from asymptomatic to a flu-like syndrome with fever, fatigue, myalgias, and sore throat, to even more severe such as shortness of breath, dry cough, high fever, pneumonia, and hypoxia. In severe cases, the disease progresses rapidly and patients can develop septic shock, multiorgan dysfunction, and thrombotic diathesis. Furthermore, the disease is characterized by the presence, in the peripheral blood, of high acute phase reactants, like C-reactive protein (CRP), high levels of ferritin, fibrinogen, and D-dimers. Leukopenia (especially lymphopenia), anemia, and thrombocytopenia may also occur [12]. The aforementioned clinical manifestations and laboratory abnormalities are the result of an uncontrolled release of pro-inflammatory cytokines like IL-1 $\beta$, IL-6, IL-18, TNF $\alpha$, and chemokines occurring during the COVID-19 disease course. More specifically, once the virus has infected the alveolar cells, it takes over and begins to make copies of itself and multiply. Then, the virus propagation causes tissue injury and thus the host's innate immune system is activated. Indeed, signals driven by SARS-CoV-2 such as the pathogen-associated molecular patterns (PAMPs) (viral RNAs) and damage-associated molecular patterns (DAMPs) (cellular debris) act on resident tissue cells-macrophages (MФs) and dendritic cells (DCs) — which activate and try to protect the host against the invader. MФs recognize SARS-CoV-2 through ACE2 and other sensors such as the Toll-like receptors (TLRs) and NOD-like receptors (NLRs), leading to further release of pro-inflammatory cytokines and chemokines. MФs can also present viral RNA to T cells and mount the adaptive immune response consisting of $\mathrm{T}$ cell activation and the generation and release of many cytokines leading to CRS $[1,13,14]$. In addition, $\mathrm{B}$ cells can be activated with the production of antibodies against the viral proteins (Fig. 1). MФ-driven inflammation leads to NLR pyrin protein 3 (NLRP3) inflammasome and caspase- 1 activation to generation and release of IL-1 $\beta$. Activation of MФs leads also to the production of IL-6, TNF $\alpha$, and other cytokines. These cytokines cause increased vascular permeability, upregulation of adhesion molecules on endothelial cells (E-selectins) and leukocytes (L-selectins), as well as recruitment of neutrophils and monocytes in the setting of inflammation. Then, neutrophils invade the host tissue through the inflamed endothelium and cause tissue damage, initially in the lung parenchyma and later on to other organs. When neutrophils migrate and invade the inflamed tissue, they degranulate releasing further proinflammatory cytokines, proteases, superoxide (oxygen radicals), and $\alpha$-defensin, which inhibit tissue factor pathway inhibitor with generation of thrombin, platelet activation, and thrombosis (Fig. 2) [11, 14].

\section{COLCHICINE'S MODE OF ACTION}

Colchicine is a tricyclic lipid-soluble alkaloid extracted from the plant colchicum autumn crocus and it is one of the oldest anti-inflammatory drugs. In rheumatic diseases colchicine is widely used for the treatment of acute gout arthritis, prophylaxis against gout flares, and treatment of CPPD and FMF [6, 7]. In addition, it is used off-label in some heart diseases like pericarditis, myocardial infarction, and others [15]. Its primary mechanism of action is tubulin disruption leading to downregulation of multiple inflammatory pathways and modulation of innate immunity. More specifically, colchicine has the capacity to bind to tubulins, thus blocking the assembly of microtubule polymerization. Microtubules are key components of the cytoskeleton and are involved in many cellular processes (maintaining the cell shape, intracellular trafficking, regulation of ion channels, cell deviation and mitosis, as well as cytokine and chemokine generation and release). At low concentrations, colchicine arrests microtubule growth and at high concentrations it promotes microtubule depolymerization [6-8]. Thus, the main mechanisms of action on innate immune response include the inhibition of neutrophil chemotaxis, neutrophil adhesion, mobilization and recruitment, inhibition of superoxide and $\alpha$-defensin from 


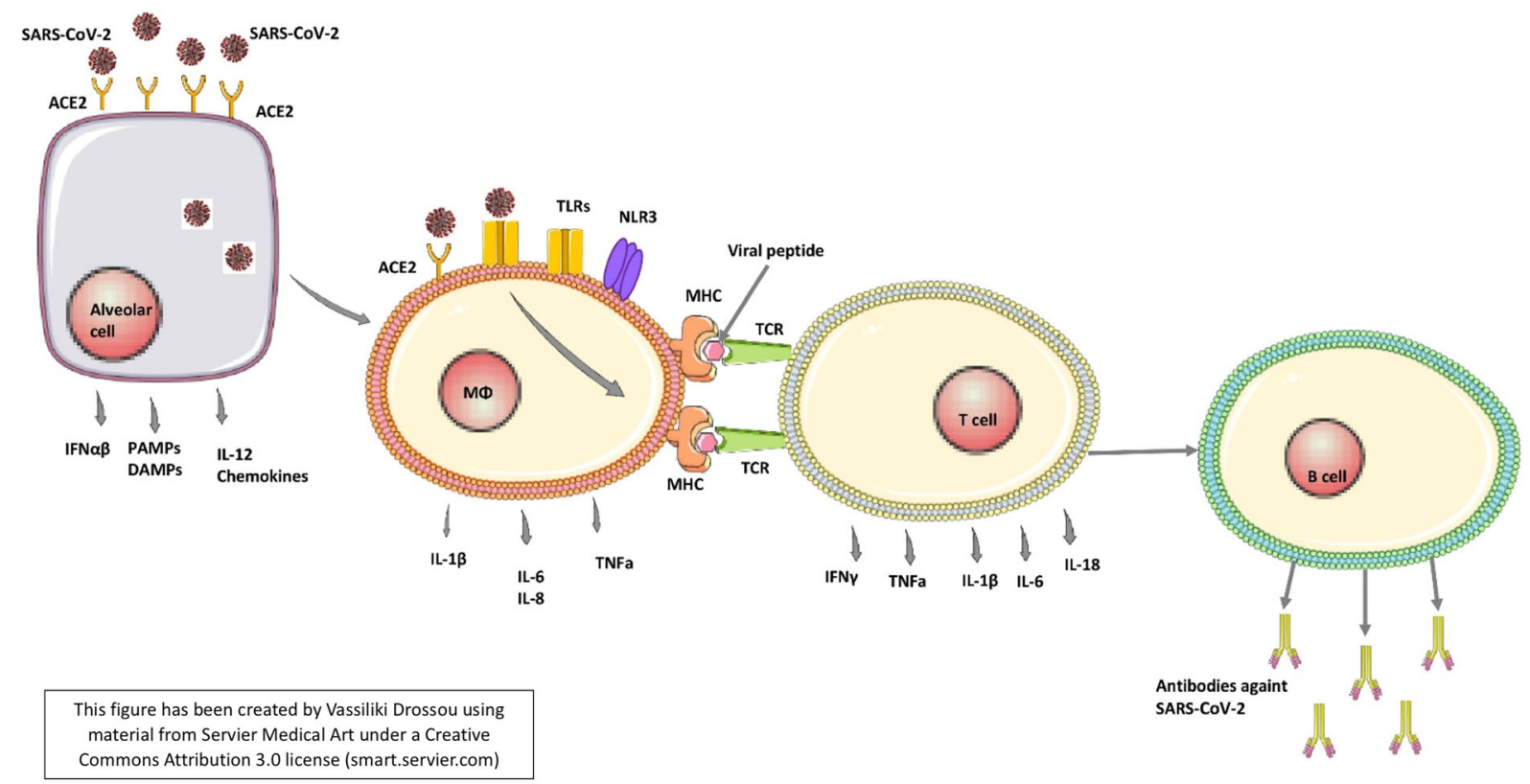

Fig. 1 SARS-CoV-2 infection and exaggerated inflammatory response by innate and adoptive immunity. ACE2 angiotensin-converting enzyme $2, I F N-\alpha \beta$ interferon- $\alpha \beta$, IL-12 interleukin-12, PAMPs pathogen associated molecular patterns, DAMPs damage associated molecular

neutrophils, and inhibition of NLRP3 inflammasome (Fig. 2). Indeed, it is known that monosodium urate (MSU) and calcium pyrophosphate dehydrate (CPP) crystals potentially stimulate a characteristic protein tyrosine phosphorylation pattern in human neutrophils. Precipitation of MSU and CPP crystals are responsible for the development of gout arthritis and CPPD, respectively. In a study by Roberge et al. the effects of colchicine on protein tyrosine phosphorylation induced by MSU and CPP crystals in human blood neutrophils were investigated. The results showed that colchicine specifically and significantly inhibits the protein tyrosine phosphorylation and suggests that its effects are associated with its intervention with microtubules [16]. This interaction blocks NLRP3 inflammasome formation and activation by inhibiting microtubule polymerization and attenuates МФs NLRP3 inflammasome arrangement and activation [17]. Through microtubule depolymerization, colchicine interferes with the recruitment patterns, $I L-1 \beta$ interleukin-1 $\beta, I L-6$ interleukin-6, $I L-8$ interleukin-8,TNFa tumor necrosis factor alpha, TLRs Toll-like receptors, NLR3 NOD-like receptor 3, MHC major histocompatibility complex, TCR T cell receptor

and adhesion to the inflamed tissue [18] and suppresses superoxide production by neutrophils [19]. Furthermore, in a murine model, it has been shown to inhibit neutrophil release of $\alpha$-defensin [20].

After a single dose of $0.6 \mathrm{mg}$ of colchicine, its plasma concentration is approximately $3 \mathrm{nmol} /$ L, while neutrophils can contain levels of 40-$200 \mathrm{nmol} / \mathrm{L}$ [21]. Many experiments performed in vitro used large doses of colchicine that are not feasible for use in humans. On the other hand, a standard low dose of colchicine $(0.6 \mathrm{mg})$ drastically reduced serum levels of inflammasome products and caspase- 1 monocyte production [22].

\section{COLCHICINE AND COVID-19}

For severe cases of COVID-19, the treatment requires antiviral therapy, dexamethasone, and supportive care. However, in the last year biological therapies and colchicine have been used as potential therapeutic agents against the 


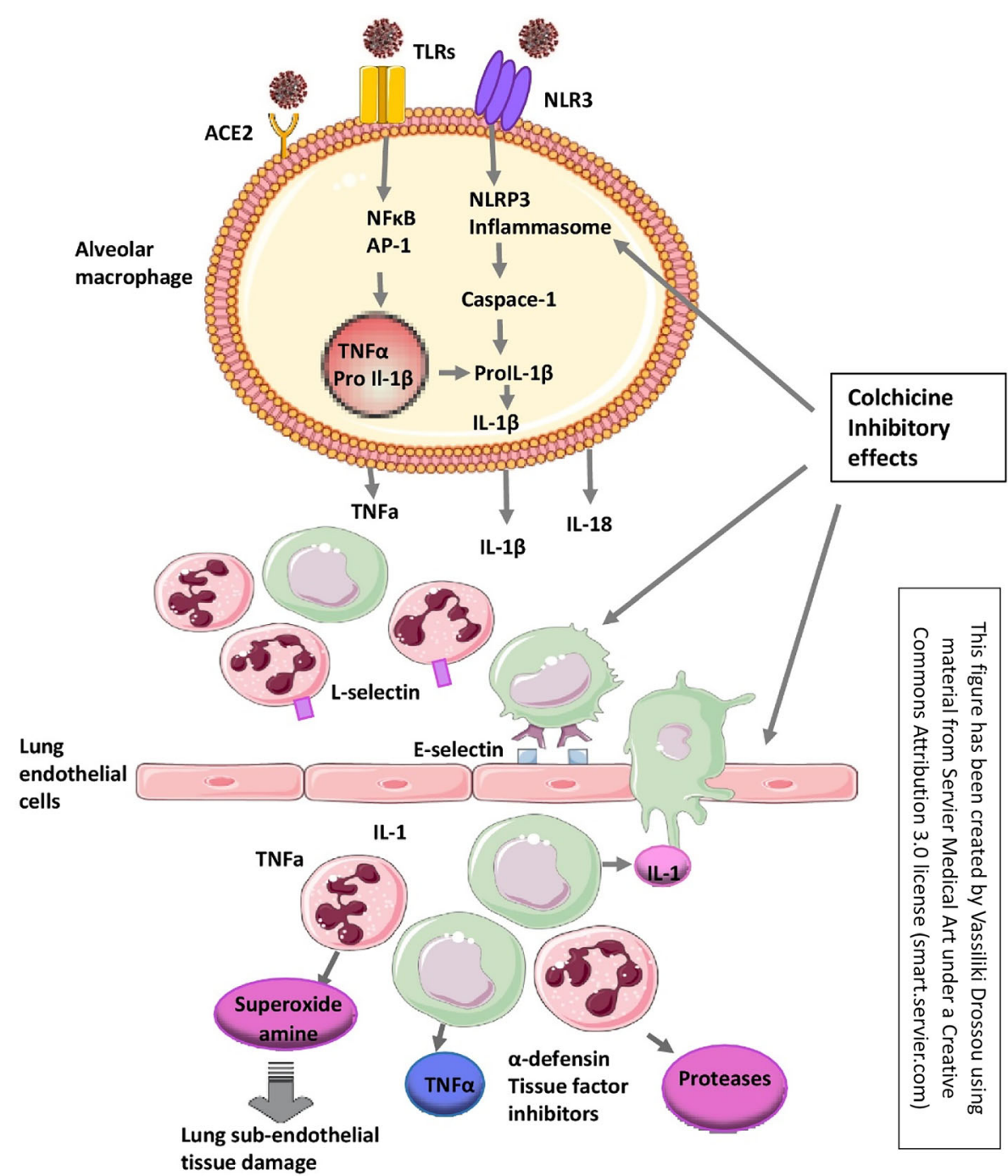

Fig. 2 SARS-CoV-2 disease pathophysiology and colchicine's inhibitory effects. ACE2 angiotensin-converting enzyme 2, TLRs Toll-like receptors, NLR3 NOD-like receptor 3, $N F \kappa B$ nuclear factor $\kappa \mathrm{B}, A P-1$ activator

SARS-CoV-2 infection $[4,8,9,17]$. Indeed, in patients with ARD who contracted COVID-19 whilst receiving biological therapies (especially cytokine inhibitors), the disease expressed with mild systemic manifestations, less hospitalization, and less severe complications [23-25]. On the other hand, in patients with FMF or gouty arthritis receiving colchicine, the disease manifested without severe respiratory complications and they recovered without additional treatment [26-28]. All the aforementioned results indicate that the chronic use of biological protein 1, TNFa tumor necrosis factor alpha, ProIL-1 $\beta$ pro-interleukin-1 $\beta, N L R P 3$ NOD-like receptor protein 3, $I L-1 \beta$ interleukin- $1 \beta$

therapies and colchicine may mitigate the clinical picture and the disease course. The question that arises here is what may biological therapies and colchicine have in common in the setting of SARS-CoV-2 infection? The answer is that both therapeutic strategies target the same pathway leading to IL-1 $\beta$ and IL-6 production-colchicine through its pleiotropic mechanism of action on neutrophils and inflammasome inhibition, while biological therapies through direct inhibition of IL-1 $\beta$ (anakinra) and IL-6 (tocilizumab). Thus, given 
the large body of evidence demonstrating the inhibitory effects on neutrophil activity, cytokine generation, inflammation and thrombosis interface, it is rational to investigate colchicine as a potential therapeutic agent against SARSCoV-2 infection $[8,17]$.

\section{COLCHICINE STUDIES IN COVID-19}

The multicenter, open-label randomized RECOVERY trial in the UK demonstrated a 28-day mortality reduction with the use of dexamethasone $(n=2104)$, versus usual care $(n=4321)$, in hospitalized patients with severe COVID-19 disease [29]. These results supported the idea that an anti-inflammatory therapeutic strategy in COVID-19 may be useful to reduce mortality. In the last few decades, several studies have demonstrated the potent anti-inflammatory effect of colchicine on gout arthritis, FMF, and its cardioprotective effects, in various clinical aspects like pericarditis, atrial fibrillation, and myocardial infarction [30-32]. On the other hand, myocardial injury appears to be a major component in COVID-19. Thus, colchicine was selected as a candidate agent to be used in these patients. The main clinical studies evaluating the effectiveness of colchicine in COVID-19 are depicted in Table 1. The GRECO19 study from Greece was the first prospective open-label randomized trial that evaluated colchicine use versus standard care (SC) in 105 early hospitalized patients. Patients receiving colchicine had a significant improvement in time to clinical deterioration and suppression of D-dimers versus the control group [9]. A second study from Italy compared 122 hospitalized patients receiving colchicine plus SC and 140 hospitalized patients receiving SC alone. The results showed that colchicine had a significant mortality benefit ( $84 \%$ vs $64 \%$ survival), when compared to control group [33]. The third prospective double-blind randomized study evaluated 38 hospitalized patients with COVID19 receiving colchicine versus 37 receiving placebo. It was demonstrated that colchicine use reduced mortality, supplemental oxygen therapy, and hospitalization [34]. In a large placebocontrolled trial $(n=4488)$ (COLCORONA),
Tardif et al. evaluated the use of colchicine in patients testing positive for SARS-CoV-2 at the time of inclusion, regardless of symptoms, with at least one identified risk factor for COVID-19 complications. This study demonstrated that patients on colchicine had lower rates of death or hospital admission than those in the placebo group [35]. In a small case series, nine outpatients with COVID-19 received colchicine, of whom only one was finally hospitalized. The hospitalized patient received oxygen therapy for 4 days and was discharged without any additional therapy [36]. Brunetti et al.'s matched cohort study evaluated 66 hospitalized patients. Of those, 33 were receiving colchicine plus SC, versus SC only. After 28 days of followup, patients on colchicine were five times more likely to be discharged with fewer deaths compared to those receiving the SC alone [37]. In a case control study, Sandhu et al. evaluated 197 patients. Patients were assigned to receive colchicine plus SC or SC only. Patients receiving colchicine had lower rates of intubation ( $47 \%$ vs $87 \%$ ) and mortality ( $47 \%$ vs $80.8 \%$ ) compared to the control group [38]. In a retrospective study, Mahale et al. evaluated 134 patients with COVID-19 who were admitted to hospital and received immunomodulatory agents (hydroxychloroquine, methylprednisolone, colchicine, etoricoxib, and tocilizumab) in different combinations. It was shown that patients receiving colchicine had reduced hospital mortality [39]. García-Posada et al.'s observational study of 209 patients with COVID-19 who were admitted to hospital evaluated the effect of (1) antibiotics plus low molecular weight heparin (LMWH) plus corticosteroids and colchicine, (2) antibiotics plus LMWH plus corticosteroids, (3) LMWH plus corticosteroids, (4) LMWH plus corticosteroids and colchicine, (5) tocilizumab. Colchicine combination therapy reduced the mortality rate, compared to other therapeutic strategies [40]. In another observational study, Kevorkian et al. evaluated the effect of a fivedrug regimen consisting of a 5-day course of prednisone, furosemide, salicylate, anti-Xa inhibitor, and colchicine in 68 hospitalized patients with COVID-19. This treatment regimen had a beneficial effect on mortality rate in these patients [41]. In a cross-sectional study 
Table 1 Clinical trials evaluating the effectiveness of colchicine against SARS-CoV-2 infection

\begin{tabular}{|c|c|c|c|c|c|}
\hline $\begin{array}{l}\text { Author, } \\
\text { reference, year, } \\
\text { country }\end{array}$ & Study design & $\begin{array}{l}\text { Number } \\
\text { of } \\
\text { patients }\end{array}$ & Colchicine dose & Setting & Outcome \\
\hline $\begin{array}{l}\text { Deftereos [9], } \\
\text { 2020, Greece }\end{array}$ & $\begin{array}{l}\text { Open-label } \\
\text { randomized }\end{array}$ & 105 & $\begin{array}{l}1.5 \mathrm{mg} \text { loading dose, then } \\
0.5 \mathrm{mg} \times 2\end{array}$ & Inpatient & $\begin{array}{l}\text { Improvement time to clinical } \\
\text { deterioration, D-dimer } \\
\text { suppression }\end{array}$ \\
\hline $\begin{array}{l}\text { Scarsi [33], 2020, } \\
\text { Italy }\end{array}$ & $\begin{array}{l}\text { Single-center } \\
\text { cohort }\end{array}$ & 272 & $1 \mathrm{mg} /$ day & Inpatient & $\begin{array}{l}\text { Significant mortality benefit } \\
\text { ( } 84 \% \text { vs } 64 \% \text { survival })\end{array}$ \\
\hline $\begin{array}{l}\text { Lopez [34], 2021, } \\
\text { Brazil }\end{array}$ & $\begin{array}{r}\text { Double-blind } \\
\text { randomized }\end{array}$ & 75 & $\begin{array}{l}0.5 \mathrm{mg} \times 3 / 5 \text { days } \\
0.5 \mathrm{mg} \times 2 . / 5 \text { days }\end{array}$ & Inpatient & $\begin{array}{l}\text { Reduced the length of death, } \\
\text { oxygen therapy, and } \\
\text { hospitalization }\end{array}$ \\
\hline $\begin{array}{l}\text { Tardif [35], } \\
\text { 2021, Canada }\end{array}$ & $\begin{array}{l}\text { Placebo } \\
\text { controlled }\end{array}$ & 4488 & $\begin{array}{c}0.5 \mathrm{mg} \times 2 / 13 \text { days then } \\
0.5 \mathrm{mg} \text { daily } / 27 \text { days }\end{array}$ & Outpatient & $\begin{array}{l}\text { Low rate of composite of death } \\
\text { and hospitalization }\end{array}$ \\
\hline $\begin{array}{l}\text { Brunetti [37], } \\
\text { 2020, USA, } \\
\text { New Jersey }\end{array}$ & $\begin{array}{r}\text { Matched } \\
\text { cohort }\end{array}$ & 66 & $\begin{array}{l}1.2 \mathrm{mg} \text { loading dose, then } \\
0.6 \mathrm{mg} \times 2\end{array}$ & Impatient & $\begin{array}{l}\text { Five times more likely to be } \\
\text { discharged, fewer deaths }\end{array}$ \\
\hline $\begin{array}{l}\text { Sandhu [38], } \\
\text { 2020, USA, } \\
\text { New York }\end{array}$ & Case control & 197 & $\begin{array}{c}0.6 \mathrm{mg} \times 2 / 3 \text { days then } \\
0.6 \mathrm{mg} \text { daily } / 12 \text { days }\end{array}$ & Inpatient & $\begin{array}{l}\text { Low rate of intubation ( } 47 \% \text { vs } \\
87 \% \text { ), lower mortality ( } 47 \% \text { vs } \\
80,8 \% \text { ) }\end{array}$ \\
\hline $\begin{array}{l}\text { Mahale [39] } \\
\text { 2020, India }\end{array}$ & Retrospective & 134 & $0.5 \mathrm{mg} /$ day for 1 week & Inpatient & Reduced mortality \\
\hline $\begin{array}{l}\text { García-Posada } \\
\text { [40], 2021, } \\
\text { Colombia }\end{array}$ & Observational & 209 & 20 days & Inpatient & Reduced mortality \\
\hline $\begin{array}{l}\text { Kevorkian }[41], \\
\text { 2021, France }\end{array}$ & Observational & 68 & $\begin{array}{l}1 \mathrm{mg} \text { followed by } 0.5 / \mathrm{h} \\
\text { later, then } 0.5 / 8 \mathrm{~h} \text { for } \\
\text { total } 8 \mathrm{mg}\end{array}$ & Inpatient & Reduced mortality \\
\hline $\begin{array}{l}\text { Pinzón [42], } \\
\text { 2021, } \\
\text { Colombia }\end{array}$ & $\begin{array}{l}\text { Cross- } \\
\text { sectional }\end{array}$ & 301 & $\begin{array}{l}0.5 \mathrm{mg} \text { twice for } \\
7-14 \text { days }\end{array}$ & Inpatient & Reduced mortality \\
\hline
\end{tabular}

Pinzón et al. evaluated the use of colchicine in 301 patients with COVID-19 pneumonia. Of these, 145 received corticosteroids plus colchicine $0.5 \mathrm{mg} \times 2$ for $7-14$ days, 95 corticosteroids alone, and 90 patients placebo. Patients receiving corticosteroids plus colchicine had better mortality rates than those receiving steroid alone [42]. Finally, Estebanez et al. proposed a randomized open-label multicenter clinical trial, in everyday clinical practice, as an early therapeutic intervention with the use of colchicine at $0.5 \mathrm{mg}$ twice for 3 days and then $0.5 \mathrm{mg}$ for 18 days in patients infected with SARS-CoV-2 over 60 years of age with at least one additional comorbidity [43]. In line with the aforementioned results, Dupuis et al. reported that colchicine reduced acute lung injury and respiratory failure in experimental 
acute respiratory distress syndrome [44]. A systematic review and meta-analysis showed that colchicine treatment was associated with a significantly lower rate of mortality in patients with COVID-19 [45]. Three more meta-analyses documented the benefit of colchicine in the treatment of patients with COVID-19. More specifically Golpour et al. reported that colchicine therapy was associated with a decreased rate of mortality and decrease in hospitalization time (days) [46]. Moreover, Salah and Mehta's meta-analysis on the effect of colchicine on mortality and mechanical ventilation in COVID-19 showed a possible mortality benefit associated with the use of colchicine in these patients [47]. In another meta-analysis, Vrachatis et al. suggest a definite benefit regarding mortality rates with the addition of colchicine in patients with COVID-19 [48].

\section{CONCLUSIONS}

All the discussed studies deal with colchicine and COVID-19, but they differ in many aspects, e.g., timing and dosing of colchicine. Furthermore, some studies measure the clinical improvement, others the laboratory results, whereas others measure a composite outcome. The optimal dose and treatment duration in patients with COVID-19 is not known. However, to prevent gout attacks the daily dose is $1-1.2 \mathrm{mg} /$ day and treatment duration is 3-9 months $[6,7]$. Finally, the timing of colchicine initiation is uncertain. Some investigators begin colchicine in the early inpatient setting, others in the outpatient setting. On the other hand, colchicine is an anti-inflammatory agent, which interferes with several inflammatory pathways, including chemotaxis, adhesion and activation of neutrophils, inflammasome activation, and cytokine release and superoxide production. Given the fact that colchicine is well tolerated, inexpensive, and has a simple dosage scheme, it holds particular promise to reduce the risk of severe COVID-19 disease in both the outpatient and inpatient setting. However, further well-designed studies with a large number of patients are needed to answer this thesis.

\section{ACKNOWLEDGEMENTS}

We gratefully thank Ms Areti Fili for her excellent secretarial assistance.

Funding. No funding or sponsorship was received for this study or publication of this article.

Authorship. All named authors meet the International Committee of Medical Journal Editors (ICMJE) criteria for authorship for this article, take responsibility for the integrity of the work as a whole, and have given their approval for this version to be published.

Author Contributions. All authors have made substantial contributions to the current manuscript and approved the final version fulfilling all the four criteria proposed be the ICMJE. EP: drafting; VD: visual graphics, drafting; PVV: revision; AAD: conception of the work, revision.

Disclosures. Alexandros A. Drosos, Eleftherios Pelechas, Vassiliki Drossou, Paraskevi V. Voulgari have nothing to disclose.

Compliance with Ethics Guidelines. This study was performed in accordance with the Helsinki Declaration of 1964 and its later amendments. Owing to the nature of the manuscript and because no sensitive data of the patients are enclosed there was no need to get permission from our university's ethics committee.

Data Availability. Data sharing is not applicable to this article as no datasets were generated or analyzed during the current study.

Open Access. This article is licensed under a Creative Commons Attribution-NonCommercial 4.0 International License, which permits any non-commercial use, sharing, adaptation, distribution and reproduction in any medium or format, as long as you give appropriate credit to the original author(s) and the source, provide a link to the Creative Commons licence, and indicate if changes were made. The images or 
other third party material in this article are included in the article's Creative Commons licence, unless indicated otherwise in a credit line to the material. If material is not included in the article's Creative Commons licence and your intended use is not permitted by statutory regulation or exceeds the permitted use, you will need to obtain permission directly from the copyright holder. To view a copy of this licence, visit http://creativecommons.org/licenses/by$\mathrm{nc} / 4.0 /$.

\section{REFERENCES}

1. Fajgenbaum DC, June CH. Cytokine storm. N Engl J Med. 2020;383(23):2255-73. https://doi.org/10. 1056/NEJMra2026131.

2. Gianfrancesco M, Hyrich KL, Al-Adely S, et al. Characteristics associated with hospitalization for COVID-19 in people with rheumatic disease: data from the COVID-19 Global Rheumatology Alliance physician-reported registry. Ann Rheum Dis. 2020;79(7):859-66. https://doi.org/10.1136/ annrheumdis-2020-217871.

3. Ferro F, Elefante E, Baldini C, et al. COVID-19: the new challenge for rheumatologists. Clin Exp Rheumatol. 2020;38(2):175-80.

4. Pelechas E, Drossou V, Voulgari PV, Drosos AA. Anti-rheumatic drugs for the fight against the novel coronavirus infection (SARS-CoV-2): what is the evidence? Mediterr J Rheumatol. 2020;31(Suppl 2): 267-89. https://doi.org/10.31138/mjr.31.3.259.

5. Sepriano A, Kerschbaumer A, Smolen JS, et al. Safety of synthetic and biological DMARDs: a systematic literature review informing the 2019 update of the EULAR recommendations for the management of rheumatoid arthritis. Ann Rheum Dis. 2020;79(6): 760-70. https://doi.org/10.1136/annrheumdis2019-216653.

6. Leung YY, Hui LLY, Kraus VB. Colchicine update on mechanisms of action and therapeutic uses. Semin Arthritis Rheum. 2015;45(3):341-50. https://doi. org/10.1016/j.semarthrit.2015.06.013.

7. Slobodnick A, Shah B, Krasnokutsky S, Pillinger MH. Update on colchicine, 2017. Rheumatology (Oxford). 2018;57(Suppl 1):i4-11. https://doi.org/ 10.1093/rheumatology/kex453.

8. Reyes AZ, Hu KA, Teperman J, et al. Anti-inflammatory therapy for COVID-19 infection: the case for colchicine. Ann Rheum Dis. 2020. https://doi. org/10.1136/annrheumdis-2020-219174.

9. Deftereos SG, Giannopoulos G, Vrachatis DA, et al. Effect of colchicine vs standard care on cardiac and inflammatory biomarkers and clinical outcomes in patients hospitalized with coronavirus disease 2019: the GRECCO-19 randomized clinical trial. JAMA Netw Open. 2020;3(6): e2013136. https://doi. org/10.1001/jamanetworkopen.2020.13136.

10. Cure CM, Kucuk A, Cure E. Colchicine may not be effective in COVID-19 infection; it may even be harmful? Clin Rheumatol. 2020;39(7):2101-2. https://doi.org/10.1007/s10067-020-05144-X.

11. Jin $\mathrm{Z}, \mathrm{Du} \mathrm{X}, \mathrm{Xu} \mathrm{Y}$, et al. Structure of Mpro from SARS-CoV-2 and discovery of its inhibitors. Nature. 2020;582:289-93. https://doi.org/10.1038/s41586020-2223-y.

12. Zhou F, Yu T, Du R, et al. Clinical course and risk factors for mortality of adult inpatients with COVID-19 in Wuhan, China: a retrospective cohort study. Lancet. 2020;395(10229):1054-62. https:// doi.org/10.1016/S0140-6736(20)30566-3.

13. Wu F, Zhao S, Yu B, et al. A new coronavirus associated with human respiratory disease in China. Nature. 2020;579(7798):265-9. https://doi.org/10. 1038/s41586-020-2008-3.

14. Cohen FS. How viruses invade cells. Biophys J. 2016;110(5):1028-32. https://doi.org/10.1016/j. bpj.2016.02.006.

15. Deftereos S, Giannopoulos G, Raisakis K, et al. Colchicine treatment for the prevention of baremetal stent restenosis in diabetic patients. J Am Coll Cardiol. 2013;61(16):1679-85. https://doi.org/ 10.1016/j.jacc.2013.01.055.

16. Roberge CJ, Gaudry M, de Médicis R, Lussier A, Poubelle PE, Naccache PH. Crystal-induced neutrophil activation. IV. Specific inhibition of tyrosine phosphorylation by colchicine. J Clin Invest. 1993;92(4):1722-9. https://doi.org/10.1172/ JCI116759.

17. Schlesinger N, Firestein BL, Brunetti L. Colchicine in COVID-19: an old drug, new use. Curr Pharmacol Rep. 2020;6:137-45. https://doi.org/10.1007/ s40495-020-00225-6.

18. Cronstein BN, Molad Y, Reibman J, Balakhane E, Levin RI, Weissmann G. Colchicine alters the quantitative and qualitative display of selectins on endothelial cells and neutrophils. J Clin Invest. 1995;96(2):994-1002. https://doi.org/10.1172/ JCI118147. 
19. Chia EW, Grainger R, Harper JL. Colchicine suppresses neutrophil superoxide production in a murine model of gouty arthritis: a rationale for use of low-dose colchicine. $\mathrm{Br} \mathrm{J}$ Pharmacol. 2008;153(6):1288-95. https://doi.org/10.1038/bjp. 2008.20.

20. Abu-Fanne R, Stepanova V, Litvinov RI, et al. Neutrophil $\alpha$-defensins promote thrombosis in vivo by altering fibrin formation, structure, and stability. Blood. 2019;133(5):481-93. https://doi.org/10. 1182/blood-2018-07-861237.

21. Dalbeth N, Lauterio TJ, Wolfe HR. Mechanism of action of colchicine in the treatment of gout. Clin Ther. 2014;36(10):1465-79. https://doi.org/10. 1016/j.clinthera.2014.07.017.

22. Robertson S, Martínez GJ, Payet CA, et al. Colchicine therapy in acute coronary syndrome patients acts on caspase- 1 to suppress NLRP3 inflammasome monocyte activation. Clin Sci (Lond). 2016;130(14):1237-46. https://doi.org/10.1042/ CS20160090.

23. Monti S, Balduzzi S, Delvino P, Bellis E, Quadrelli VS, Montecucco C. Clinical course of COVID-19 in a series of patients with chronic arthritis treated with immunosuppressive targeted therapies. Ann Rheum Dis. 2020;79(5):667-8. https://doi.org/10. 1136/annrheumdis-2020-217424.

24. Haberman RH, Castillo R, Chen A, et al. COVID-19 in patients with inflammatory arthritis: a prospective study on the effects of comorbidities and disease-modifying antirheumatic drugs on clinical outcomes. Arthririts Rheumatol. 2020;72:1981-9. https://doi.org/10.1002/art.41456.

25. Migkos MP, Kaltsonoudis E, Pelechas E, et al. Use of conventional synthetic and biologic disease-modifying anti-rheumatic drugs in patients with rheumatic diseases contracting COVID-19: a singlecenter experience. Rheumatol Int. 2021;41(5): 903-9. https://doi.org/10.1007/s00296-021-048182.

26. Bourguiba R, Delplanque M, Vinit C, et al. Clinical course of COVID-19 in a cohort of 342 familial Mediterranean fever patients with a long-term treatment by colchicine in a French endemic area. Ann Rheum Dis. 2020. https://doi.org/10.1136/ annrheumdis-2020-218707.

27. Kobak S. COVID-19 infection in a patient with FMF: does colchicine have a protective effect? Ann Rheum Dis. 2020. https://doi.org/10.1136/ annrheumdis-2020-217882.

28. Pelechas E, Drossou V, Voulgari PV, Drosos AA. COVID-19 in patients with gout on colchicine.
Rheumatol Int. 2021;5:1-5. https://doi.org/10. 1007/s00296-021-04902-7.

29. RECOVERY collaborative Group. Dexamethasone in hospitalized patients with COVID-19. N Engl J Med. 2021;384(8):693-704. https://doi.org/10. 1056/NEJMoa2021436.

30. Tardif J-C, Kouz S, Waters DD, et al. Efficacy and safety of low-dose colchicine after myocardial infarction. N Engl J Med. 2019;381:2497-505. https://doi.org/10.1056/NEJMoa1912388.

31. Russell MD, Bukhari M, Shah AM, Galloway JB. Colchicine and the heart: old friends, old foes. Rheumatology (Oxford). 2021;60(5):2035-6. https://doi.org/10.1093/rheumatology/keab062.

32. Nidorf SM, Fiolet ATL, Mosterd A, et al. Colchicine in patients with chronic coronary disease. $\mathrm{N}$ Engl J Med. 2020;383:1838-47. https://doi.org/10.1056/ NEJMoa2021372.

33. Scarsi M, Piantoni S, Colombo E, et al. Association between treatment with colchicine and improved survival in a single-centre cohort of adult hospitalized patients with COVID-19 pneumonia and acute respiratory distress syndrome. Ann Rheum Dis. 2020;79:1286-9. https://doi.org/10.1136/ annrheumdis-2020-217712.

34. Lopes MI, Bonjorno L, Giannini MC, et al. Beneficial effects of colchicine for moderate to severe COVID-19: a randomized, double-blinded, placebocontrolled clinical trial. RMD Open. 2021;7: e001455. https://doi.org/10.1136/rmdopen-2020001455 .

35. Tardif J-C, Bouabdallaoui N, L'Allier PL, et al. Colchicine for community-treated patients with COVID-19 (COLCORONA): a phase 3, randomized, double-blinded, adaptive, placebo-controlled, multicenter trial. Lancet. 2021. https://doi.org/10.1016/ S2213-2600(21)00222-8.

36. Della-Torre E, Della-Torre F, Kusanovic M, et al. Treating COVID-19 with colchicine in community healthcare setting. Clin Immunol. 2020;217: 108490. https://doi.org/10.1016/j.clim.2020. 108490.

37. Brunetti L, Diawara O, Tsai A, et al. Colchicine to weather the cytokine storm in hospitalized patients with COVID-19. J Clin Med. 2020;9(9):2961. https://doi.org/10.3390/jcm909261.

38. Sandhu E, Tieng A, Chilimuri S, Franchin G. A case control study to evaluate the impact of colchicine on patients admitted to the hospital with moderate to severe COVID-19 infection. Can J Infect Dis Med Microbiol. 2020;27(2020):8865954. https://doi.org/ $10.1155 / 2020 / 8865954$. 
39. Mahale N, Godavarthy P, Narasimhan VL, et al. A retrospective observational study of hypoxic COVID-19 patients treated with immunomodulatory drugs in a tertiary care hospital. Indian J Crit Care Med. 2020;24(11):1020-7. https://doi.org/10. 5005/jp-journals-10071-23599.

40. García-Posada M, Aruachan-Vesga S, Mestra D, et al. Clinical outcomes of patients hospitalized for COVID-19 and evidence-based on the pharmacological management reduce mortality in a region of the Colombian Caribbean. J Infect Public Health. 2021;14(6):696-701. https://doi.org/10.1016/j.jiph. 2021.02.013.

41. Kevorkian JP, Lopes A, Sène D, et al. Oral corticoid, aspirin, anticoagulant, colchicine, and furosemide to improve the outcome of hospitalized COVID-19 patients the COCAA-COLA cohort study. J Infect. 2021;82(6):276-316. https://doi.org/10.1016/j.jinf. 2021.02.008.

42. Pinzón MA, Cardona Arango D, Betancur JF, et al. Clinical outcome of patients with COVID-19 pneumonia treated with corticosteroids and colchicine in Colombia. Ann Clin Microbiol Antimicrob. 2021;20(1):66. https://doi.org/10.1186/ s12941-021-00460-9.

43. Estebanez EB, Alconero LL, Fernández BJ, et al. The effectiveness of early colchicine administration in patients over 60 years old with high risk of developing severe pulmonary complications associated with coronavirus pneumonia SARS-CoV-2 (COVID-
19): study protocol for an investigator-driven randomized controlled clinical trial in primary health care-COLCHICOVID study. Trials. 2021;22(1): 590. https://doi.org/10.1186/s13063-021-05544-7.

44. Dupuis J, Sirois MG, Rheuaume E, et al. Colchicine reduces lung injury in experimental acute respiratory distress syndrome. PLOS ONE. 2020;15(12): e0242318. https://doi.org/10.1371/journal.pone. 0242318 .

45. Lien $\mathrm{CH}$, Lee MD, Weng SL, et al. Repurposing colchicine in treating patients with COVID-19: a systematic review and meta-analysis. Life (Basel). 2021;11(8):864. https://doi.org/10.3390/ life11080864.

46. Golpour M, Mousavi T, Alimohammadi M, et al. The effectiveness of colchicine as an anti-inflammatory drug in the treatment of coronavirus disease 2019: meta-analysis. Int J Immunopathol Pharmacol. 2021;35:20587384211031764. https://doi.org/ $10.1177 / 20587384211031763$

47. Salah HM, Mehta JL. Meta-analysis of the effect of colchicine on mortality and mechanical ventilation in COVID-19. Am J Cardiol. 2021;145:170-2. https://doi.org/10.1016/j.amjcard.2021.02.005.

48. Vrachatis DA, Giannopoulos GV, Giotaki SG, et al. Impact of colchicine on mortality in patients with COVID-19: a meta-analysis. Hellenic J Cardiol. 2021. https://doi.org/10.1016/j.hjc.2020.11.012. 